\title{
Effect of hormonal and energy-related factors on plasma adiponectin in transition dairy cows
}

\author{
C. S. Krumm, ${ }^{*}$ S. L. Giesy, ${ }^{*}$ L. S. Caixeta, ${ }^{*}$ W. R. Butler, ${ }^{*}$ H. Sauerwein,† J. W. Kim, $\ddagger$ and Y. R. Boisclair*1 \\ *Department of Animal Science, Cornell University, Ithaca, NY 14853 \\ †Institute for Animal Science, Physiology and Hygiene Unit, University of Bonn, 53115 Bonn, Germany \\ ‡Department of Animal Bioscience, Institute of Agriculture and Life Science, Gyeongsang National University, Jinju 660-701, South Korea
}

\begin{abstract}
In transition dairy cows, plasma levels of the insulinsensitizing hormone adiponectin fall to a nadir at parturition and recover in early lactation. The transition period is also characterized by rapid changes in metabolic and hormonal factors implicated in other species as positive regulators of adiponectin production (i.e., negative energy balance, lipid mobilization) and others as negative regulators (i.e., reduced leptin and insulin and increased growth hormone and plasma fatty acids). To assess the role of onset of negative energy balance and lipid mobilization after parturition, dairy cows were either milked thrice daily (lactating) or never milked (nonlactating) for up to 4 wk after parturition. Plasma adiponectin was $21 \%$ higher across time in nonlactating than lactating cows. Moreover, nonlactating cows recovered plasma adiponectin at similar rates as lactating cows even though they failed to lose body condition. Next, we assessed the ability of individual hormones to alter plasma adiponectin in transition dairy cows. In the first experiment, dairy cows received a constant 96-h intravenous infusion of either saline or recombinant human leptin starting on d 8 of lactation. In the second experiment, dairy cows were studied in late pregnancy (LP, starting on prepartum d -31) and again in early lactation (EL, starting on d 7 postpartum) during a $66-\mathrm{h}$ period of basal sampling followed by $48 \mathrm{~h}$ of hyperinsulinemic-euglycemia. In the third experiment, cows were studied either in LP (starting on $\mathrm{d}-40$ prepartum) or EL (starting on d 7 postpartum) during a 3-h period of basal sampling followed by $5 \mathrm{~d}$ of bovine somatotropin treatment. Plasma adiponectin was reduced by an average of $21 \%$ in EL relative to LP in these experiments, but neither leptin, insulin, or growth hormone treatment affected adiponectin in LP or EL. Finally, the possibility that plasma fatty acids repress plasma adiponectin was evaluated by in-
\end{abstract}

Received June 1, 2017.

Accepted July 13, 2017.

${ }^{1}$ Corresponding author: yrb1@cornell.edu travenous infusion of a lipid emulsion in nonpregnant, nonlactating cows in the absence or presence of glucagon for 16 consecutive hours. The intralipid infusion increased plasma fatty acid concentration from 102 to over $570 \mu M$ within $3 \mathrm{~h}$ but had no effect on plasma adiponectin irrespective of presence or absence of glucagon. Overall, these data suggest that energy balance around parturition may regulate plasma adiponectin but do not support roles for lipid mobilization or sustained changes in the plasma concentration of leptin, insulin, growth hormone, or fatty acids.

Key words: energy insufficiency, lipid mobilization, insulin, leptin, growth hormone

\section{INTRODUCTION}

Adiponectin is a $30-\mathrm{kDa}$ protein hormone synthesized exclusively by adipose tissue (Kadowaki et al., 2006; Wang and Scherer, 2016). Adiponectin circulates as a homomultimer consisting of low molecular weight, medium molecular weight, and high molecular weight complexes containing 3,6 , or 18 or more adiponectin monomers (Wang et al., 2008; Wang and Scherer, 2016). Adiponectin signals through 2 membrane-bound receptors, adiponectin receptor 1 and adiponectin receptor 2 , which are found in most tissues including liver, muscle, and adipose tissue (Kadowaki et al., 2006). Many lines of evidence suggest that adiponectin is an insulin sensitizer. First, decreased plasma adiponectin is observed in conditions and diseases characterized by insulin resistance (IR) such as obesity and type 2 diabetes (Kadowaki et al., 2006; Wang and Scherer, 2016). This inverse relation between IR and plasma adiponectin has been found not only in humans but also in various animal models ranging from nonhuman primates to dolphins (Hotta et al., 2001; Venn-Watson et al., 2013). Second, administration of recombinant adiponectin improved insulin action in various mouse models of IR (diet-induced obese, lipoatrophic, db/db, and $\mathrm{KKA}^{\mathrm{y}}$; Kadowaki et al., 2006). Third, mutations leading to adiponectin loss of function promote IR in both mice and humans (Kadowaki et al., 2006), whereas 
adiponectin overexpression in ob/ob mice is sufficient to normalize their excessive circulating levels of glucose and insulin (Kim et al., 2007).

We have demonstrated that the plasma concentration of adiponectin varies in a quadratic manner in transition dairy cows with the highest levels in late pregnancy (LP), a nadir on the day of parturition, and a progressive return to LP values over the first few weeks of lactation (Giesy et al., 2012; Mielenz et al., 2013). This adiponectin profile occurs in parallel with the development of IR and the onset of negative energy balance (NEB) and coincides with rapid reduction in plasma insulin and leptin and reciprocal changes in plasma growth hormone $(\mathbf{G H})$ and fatty acids (Block et al., 2001; Rhoads et al., 2004; Giesy et al., 2012). Evidence in rodents and humans indicates involvement of these factors in regulating adiponectin production (Delporte et al., 2004; Bobbert et al., 2009; Lubbers et al., 2013), but whether they contribute to variation in plasma adiponectin in transition dairy cows remains unknown.

The objectives of the present study were to determine first whether the onset of NEB around parturition contributes to reduced plasma adiponectin and second whether sudden changes in the plasma concentrations of leptin, insulin, $\mathrm{GH}$, or fatty acids regulate plasma adiponectin. Our results demonstrate that plasma adiponectin is sensitive to changes in energy balance in the immediate post-periparturient period but rule out leptin, insulin, GH, or fatty acids as factors contributing to reduced plasma adiponectin in transition dairy cows.

\section{MATERIALS AND METHODS}

\section{Animals and Design}

Samples analyzed were from 5 previous experiments designed to identify effects of variation in energy balance, leptin, insulin, GH, or fatty acids (Block et al., 2001; Leury et al., 2003; Schoenberg et al., 2011; Ehrhardt et al., 2016; Caixeta et al., 2017). All experiments were performed in multiparous Holstein cows at Cornell University and were approved by the Cornell Institutional Animal Care and Use Committee. Procedures common to all experiments included housing in individual stalls and blood collection from chronic intrajugular catheters. Blood was processed to plasma by the addition of sodium heparin $(15 \mathrm{IU} / \mathrm{mL})$ and centrifugation. Unless otherwise mentioned, cows were fed unlimited amounts of TMR using automatic feeders and milked daily at 0600 and $1800 \mathrm{~h}$ after parturition. Experiments and associated specific procedures were as follows.

\section{Effect of the Periparturient Period and Leptin}

The study of Ehrhardt et al. (2016) was used to compare 2 assays in their ability to detect changes in plasma adiponectin between LP and early lactation (EL) and to assess the effects of leptin therapy in EL. Ten cows were fed unlimited amounts of TMR formulated for each physiological stage $\left(1.5 \mathrm{Mcal}\right.$ of $\mathrm{NE}_{\mathrm{L}}$ and $140 \mathrm{~g}$ of CP per $\mathrm{kg}$ of $\mathrm{DM}$ in $\mathrm{LP}$ and $1.5 \mathrm{Mcal}$ of $\mathrm{NE}_{\mathrm{L}}$ and $180 \mathrm{~g}$ of $\mathrm{CP}$ per $\mathrm{kg}$ of DM in EL). Plasma adiponectin was analyzed on 4 blood samples collected at 2-h intervals between 0800 and $1400 \mathrm{~h}$ in LP (d -29 \pm 2 , relative to parturition $\mathrm{d} 0)$ and again in EL $(\mathrm{d}+8)$. After completing blood sampling on $\mathrm{d}+8$, cows were randomly assigned to receive a continuous intrajugular infusion of saline (saline) or human leptin (hLeptin, 61 $\mu \mathrm{g} / \mathrm{kg}$ of BW/d; Eli Lilly and Company, Indianapolis, IN) for 96 consecutive hours. Plasma adiponectin was measured on 4 samples collected from each cow at 2-h intervals between 88 and $94 \mathrm{~h}$ of infusion.

\section{Energy Balance After Parturition}

An experiment described in Block et al. (2001) was used to evaluate the effect of positive energy balance after parturition on the recovery of plasma adiponectin. Between parturition and $\mathrm{d}+32$ of lactation, cows were offered a low-energy TMR (1.52 Mcal of $\mathrm{NE}_{\mathrm{L}}$ and 189 $\mathrm{g}$ of $\mathrm{CP}$ per $\mathrm{kg}$ of $\mathrm{DM}$ ) and milked thrice daily at 0900 , 1600 , and $2300 \mathrm{~h}$ (lactating, $\mathrm{n}=7$ ) or offered a highenergy TMR (1.70 Mcal of $\mathrm{NE}_{\mathrm{L}}$ and $188 \mathrm{~g}$ of CP per $\mathrm{kg}$ of $\mathrm{DM}$ ) and never milked (nonlactating, $\mathrm{n}=7$ ). Lactating cows were fed ad libitum during the first week postpartum and thereafter limited to amounts consumed on $\mathrm{d}+7(13.6 \pm 1.2 \mathrm{~kg} / \mathrm{d})$; nonlactating cows were fed ad libitum at all times. Each cow was scored for body condition (thin $=1$; fat $=5$ ) on wk 1 and 4 by 2 independent individuals as previously described (Block et al., 2001). Plasma variables including adiponectin were analyzed on 4 blood samples collected from each cow every other day between $\mathrm{d}+5$ and +11 and again between $\mathrm{d}+26$ and +32 .

\section{Effect of Insulin}

The study of Leury et al. (2003) was used to assess the effect of chronic hyperinsulinemia during the transition period on plasma adiponectin. Six cows were fed unlimited amounts of appropriate TMR during LP (1.56 Mcal of $\mathrm{NE}_{\mathrm{L}}$ and $140 \mathrm{~g}$ of $\mathrm{CP}$ per $\mathrm{kg}$ of $\mathrm{DM}$ ) and EL (1.58 Mcal of $\mathrm{NE}_{\mathrm{L}}$ and $198 \mathrm{~g}$ of CP per $\mathrm{kg}$ of DM). The cows were subjected to the hyperinsulinemiceuglycemic clamp procedure starting on $\mathrm{d}-31 \pm 1.5$ of LP and $d+7 \pm 1.6$ of EL. The clamp procedure 
involved a 66 -h period of basal blood sampling followed by infusion of bovine insulin at the rate of $1 \mu \mathrm{g} / \mathrm{kg}$ of BW per hour for $96 \mathrm{~h}$ in LP and $48 \mathrm{~h}$ in EL. During insulin infusion, plasma glucose levels were maintained to the concentration observed during the basal period by varying the rate of infusion of a $50 \%$ (wt/vol) dextrose solution (Leury et al., 2003). Plasma adiponectin was determined on samples collected during the basal period $(-66,-43,-30$, and $0 \mathrm{~h}$, relative to initiation of insulin infusion) and on 4 plasma samples collected from each cow at 4 -h intervals between 36 and $48 \mathrm{~h}$ and 84 and $96 \mathrm{~h}$ of hyperinsulinemia during LP and between 36 and $48 \mathrm{~h}$ of hyperinsulinemia during EL.

\section{Effect of $G H$}

An experiment described in Schoenberg et al. (2011) was used to assess the effect of chronic GH treatment during the transition period on plasma adiponectin. In brief, cows were studied over a 5-d period either in LP ( $\mathrm{d}-40$ to -36 , relative to parturition on $\mathrm{d} 0, \mathrm{n}=7$ ) or EL $(\mathrm{d}+7$ to $+11, \mathrm{n}=7)$. Cows were offered unlimited amounts of TMR appropriate for each physiological stage (1.52 Mcal of $\mathrm{NE}_{\mathrm{L}}$ and $142 \mathrm{~g}$ of $\mathrm{CP}$ per $\mathrm{kg}$ of DM in $\mathrm{LP}$ and $1.72 \mathrm{Mcal}$ of $\mathrm{NE}_{\mathrm{L}}$ and $179 \mathrm{~g}$ of $\mathrm{CP}$ per $\mathrm{kg}$ of DM in EL). On the first day of each period, basal blood samples were collected hourly over a 3 -h period, followed by biopsy of adipose tissue from the tail-head subcutaneous depot. Immediately afterward, cows received an intrajugular bolus of $\mathrm{GH}(20 \mu \mathrm{g}$ of recombinant bST per kg of BW; Monsanto Co., St. Louis, MO) and a second adipose tissue biopsy was taken $15 \mathrm{~min}$ later. The GH treatment was continued over the next $4 \mathrm{~d}$ via daily i.m. injections of $40 \mathrm{mg} / \mathrm{d}$ of recombinant bST. Blood samples were collected from each cow at hourly intervals between 1000 and $1300 \mathrm{~h}$ on the last day of treatment. Plasma IGF-I and adiponectin were analyzed on samples collected during basal sampling and on $\mathrm{d} 5$ of GH treatment.

\section{Effect of Elevated Plasma Fatty Acids}

The study of Caixeta et al. (2017) was used to assess the effects of increased plasma fatty acids on plasma adiponectin. Six nonpregnant, nonlactating dairy cows consumed a single TMR (1.54 Mcal of $\mathrm{NE}_{\mathrm{L}}$ and $143 \mathrm{~g}$ of $\mathrm{CP}$ per $\mathrm{kg}$ of $\mathrm{DM}$ ) in amounts covering $121 \%$ of energy requirements according to the NRC (2001) throughout the entire experiment. Cows were randomly assigned to two $3 \times 3$ Latin squares with experimental periods of $17 \mathrm{~h}$ separated by 3 -d intervals. Each experimental period included basal blood sampling over $1 \mathrm{~h}$ followed by a 16 -h period of treatment. Treatments consisted of various combinations of s.c. injections of saline or bo- vine glucagon (Eli Lilly and Company) and i.v. infusion of saline or 20\% intralipid solution (Frasenius, Kabi, Deerfield, IL). These treatments were i.v. infusion and s.c. injections of saline (saline), i.v. infusion of intralipid and s.c. injection of saline (intralipid) and i.v. infusion of intralipid and s.c. injection of glucagon (intralipid + glucagon). Intralipid and saline solutions were infused at the rate of $100 \mathrm{~mL} / \mathrm{h}$ for 16 consecutive hours and glucagon was administered at the dose of $5 \mathrm{mg}$ at 0 and $8 \mathrm{~h}$ relative to the start of treatment. Blood samples were obtained from each cow during the basal period $(-1$ and $-0.5 \mathrm{~h}$ relative to treatment at $0 \mathrm{~h})$ and during treatment $(0,+3,+7,+10,+13$, and $+16 \mathrm{~h})$ analyzed for plasma fatty acids and adiponectin.

\section{Analysis of Metabolites and Hormones}

Plasma fatty acids were measured by the acyl-CoA synthetase/oxidase method described previously (Block et al., 2001). Plasma insulin and IGF-I were measured with double-antibody RIA as previously described (Block et al., 2001; Leury et al., 2003; Rhoads et al., 2004). Plasma leptin was measured with a doubleantibody RIA detecting only hLeptin (Linco Research Inc., St. Charles, MI) or bovine leptin (Ehrhardt et al., 2016). Effective leptin concentration in hLeptin-infused cows was calculated as the sum of bovine leptin plus human leptin corrected for its ability to activate the bovine leptin receptor (Ehrhardt et al., 2016). Interassay and intraassay coefficients of variation for these assays averaged less than 6 and $8 \%$, respectively.

Plasma adiponectin was measured by an indirect competitive ELISA designed to measure bovine adiponectin (Mielenz et al., 2013). The assay was performed as originally described, except for the following modifications. The calibration curve was prepared by a 4 -fold serial dilution of the reference serum and ranged from 0.08 to $20 \mathrm{ng} / \mathrm{mL}$. Other modifications included dilution of samples $(1: 20,000$ instead of $1: 80,000)$, volume of diluted samples and standards inputted in the assay (20 $\mu \mathrm{L}$ instead of $50 \mu \mathrm{L}$ ), and dilution of the primary antibody (1:5,000 instead of 1:2,000). The assay was developed with $100 \mu \mathrm{L}$ of secondary antibody [donkey anti-rabbit horseradish peroxidase (Jackson ImmunoResearch \#711-035-152, West Grove, PA); 1:15,000 dilution in assay buffer], and $100 \mu \mathrm{L}$ of substrate solution [SureBlue TMB Microwell Peroxidase Substrate (KPL), Gaithersburg, MD]. The reaction was stopped by adding $100 \mu \mathrm{L}$ of TMB stop solution (KPL) followed by reading of the optical density at $450 \mathrm{~nm}$ with a microplate reader. Inter-assay and intraassay coefficients of variation for all assays averaged less than 6.4 and $8 \%$, respectively. Plasma adiponectin was also measured in a subset of samples by Western immu- 
noblotting exactly as described recently (Giesy et al., 2012). In brief, plasma samples $(1.5 \mu \mathrm{L}$ of $1: 10$ dilution for plasma) were electrophoresed under reducing conditions on $13 \%$ SDS PAGE gels and electroblotted onto nitrocellulose membranes (Protran, Schleicher \& Schuell Bioscience, Keene, NH). The membranes were incubated with bovine adiponectin antiserum (1:1,000 dilution) and developed with a 1:20,000 dilution of IR Dye $800-n m$ goat anti-rabbit secondary antibody (LICOR Biotechnology, Lincoln, NE). Signals were quantified with the LI-COR Odyssey infrared imaging system using the $800-\mathrm{nm}$ channel.

\section{Western Immunoblotting of Adipose Tissue Extract}

Bovine adipose tissue was homogenized in $2 \mathrm{~mL}$ of lysis buffer $[10 \mathrm{~m} M$ Tris, $\mathrm{pH} 7.6,10 \mathrm{~mL} / \mathrm{L}$ of Triton X-100, $1 \mathrm{~m} M$ EGTA, $150 \mathrm{~m} M \mathrm{NaCl}, 1 \mathrm{~m} M \mathrm{Na}_{3} \mathrm{VO}_{4}, 1$ $\mathrm{m} M \mathrm{Na}$ pyrophosphate, $10 \mathrm{~m} M \mathrm{NaF}, 1 \mathrm{~m} M$ EDTA, 1 $\mathrm{m} M$ phenylmethylsulfonyl fluoride, $10 \mathrm{mg} / \mathrm{L}$ of aprotinin, and $10 \mathrm{mg} / \mathrm{L}$ of leupeptin]. Homogenates were clarified by centrifugation $(10,000 \times g$ for $20 \mathrm{~min}$ at $4^{\circ} \mathrm{C}$ ). Protein concentrations of cellular extracts were determined using a bicinchoninic acid assay protein assay kit (Thermo Fisher, Waltham, MA). Fixed amounts $(55 \mu \mathrm{g})$ of protein extract were separated on $10 \%$ polyacrylamide gels and transferred onto nitrocellulose membranes (Protran, Schleicher, and Schuell Bioscience, Dassel, Germany). Membranes were immersed in blocking solution (50 mM Tris, pH 7.4, $200 \mathrm{mM} \mathrm{NaCl}$, $1 \mathrm{~mL} / \mathrm{L}$ of Tween 20,50 g/L of nonfat dried skim milk). Membranes were then immunodecorated overnight at $4^{\circ} \mathrm{C}$ with a 1:4,000 dilution of antibodies against signal transducer and activator of transcription-5 (STAT5; Cell Signaling, Danvers, MA) or a 1:1,000 dilution of antibodies against tyrosine phosphorylated Stat5 (pSTAT5; Cell Signaling). Signals were developed with a 1:5,000 dilution of goat anti-rabbit antibody (Thermo Fisher) in 5\% nonfat dried skim milk and visualized by chemiluminescence exposure to film (Super Signal West Pico Chemiluminescent Substrate, Thermo Fisher). Signals were quantified by densitometry using the National Institutes of Health 1.6.3 software (National Institutes of Health, Bethesda, MD).

\section{Statistical Analysis}

Data were analyzed by a mixed model using the fit model procedure of JMP Pro 11.0 statistical software (SAS Institute Inc., Cary, NC). Data from the periparturient period study were analyzed by a mixed model accounting for physiological stage (LP or EL) as the fixed effect and cow as the random effect. For the leptin infusion portion of the experiment, data were analyzed with the fixed effect of treatment (control or hLeptin) and cow as the random effect with data obtained on d 8 used as a covariate. For the energy balance study, the mixed model accounted for treatment (lactating vs. nonlactating), time (wk 1 vs. 4), and their interaction as fixed effects and cow as the random effect. For the insulin and GH studies, the mixed model accounted for physiological stage (LP vs. EL), treatment (either basal vs. insulin or GH), and their interaction as fixed effects and cow as the random effect. For the plasma fatty acid study, the mixed model accounted for treatment (saline, intralipid, and intralipid + glucagon), time $(0,3,7,10$, 13 , and $16 \mathrm{~h}$ ), and their interaction as fixed effects, and cow as the random effect. Values obtained during the basal period (average of -1 and $-0.5 \mathrm{~h}$ samples) were used as a covariate. Correlations between plasma adiponectin and other variables were performed using the fit model procedure of JMP. Statistical significance was set at $P<0.05$.

\section{RESULTS}

\section{Comparison of Adiponectin Assays}

In previous work, we reported a $30 \%$ reduction in plasma adiponectin between $\mathrm{d}-35$ and +7 relative to parturition on d 0 when measured by Western immunoblotting (Giesy et al., 2012). This technique has limited applicability for the analysis of numerous samples across multiple studies. Accordingly, we used the transition cow study of Ehrhardt et al. (2016) to compare a recently developed bovine adiponectin ELISA to the Western immunoblotting assay. Energy indicators in that study varied as expected, with energy balance and plasma fatty acids averaging 12.1 Mcal of $\mathrm{NE}_{\mathrm{L}}$ per $\mathrm{d}$ and $108 \mu M$ in LP and $-15.2 \mathrm{Mcal}$ of $\mathrm{NE}_{\mathrm{L}}$ per $\mathrm{d}$ and $386 \mu M$ in EL. When measured by ELISA, plasma adiponectin fell from 51 to $36 \mu \mathrm{g} / \mathrm{mL}$ between d -29 of LP and d 8 of EL $(P<0.05)$. Moreover, both assays gave similar relative reductions in plasma adiponectin between LP and EL (Figure 1A). The ELISA assay was adopted for all subsequent analyses.

\section{Effect of Energy Balance Immediately After Parturition}

Next, we analyzed samples from cows milked thrice daily (lactating) or never milked after parturition (nonlactating) to ask whether eliminating the energy deficit of EL affected plasma adiponectin. Daily energy balance and the change in BCS over the 4 wk of the study were $-16.8 \mathrm{Mcal}$ of $\mathrm{NE}_{\mathrm{L}}$ and -0.6 units for lactating cows, and +12.1 Mcal of $\mathrm{NE}_{\mathrm{L}}$ and 0.1 unit for nonlactating cows $(P<0.001$ for both variables). 
Plasma adiponectin increased by an average of $24 \%$ in both groups between wk 1 and 4 (Figure 2A, time, $P$ $<0.001)$ and was $21 \%$ higher across time in nonlactating than lactating cows (treatment, $P<0.05$ ). When assessed across treatments, no relation existed between the change in body condition over this period and the change in plasma adiponectin (Figure 2B). Modest relations were observed, however, between adiponectin and plasma indicators of energy status, with adiponectin increasing with leptin or insulin and decreasing with plasma fatty acids (Figure $2 \mathrm{C}$ and results not shown, $P$ $<0.05$ or less).

\section{Reversal of the Insulin and Leptin Deficits of Early Lactation}

The plasma concentrations of leptin and insulin fall over the last few days of pregnancy and reach a nadir after parturition (Block et al., 2001; Rhoads et al., 2004). To determine whether a fall in plasma leptin contributes to reduced adiponectin, cows received continuous i.v. infusions of saline or hLeptin between $\mathrm{d}$ 8 and 12 of lactation. Relative to saline infusion, the hLeptin infusion caused a 3.5 -fold increase in the effective plasma leptin concentration $(2.3$ vs. $8 \mathrm{ng} / \mathrm{mL}, P<$ $0.001)$ and a $45 \%$ increase in plasma $\mathrm{T}_{3}$ (0.91 vs. 1.32 $\mathrm{ng} / \mathrm{mL}, P<0.01)$, but did not affect energy variables such as feed intake and milk energy output (Ehrhardt et al., 2016). Plasma adiponectin remained unaffected after $94 \mathrm{~h}$ of hLeptin treatment (Figure 1B).
A

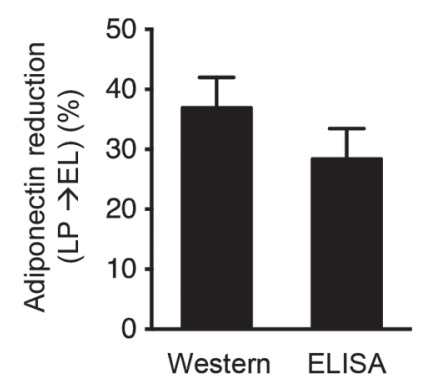

B

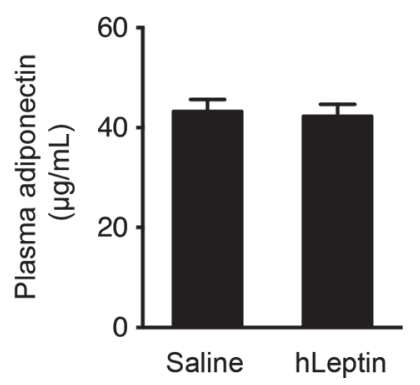

Figure 1. Comparison of adiponectin assays and effect of increased plasma leptin in early lactation on plasma adiponectin. Multiparous dairy cows were studied in late pregnancy (LP) on d $-29 \pm 2$ (relative to parturition on $\mathrm{d} 0$ ) and again in early lactation (EL) on $\mathrm{d}+8$. (A) Plasma samples were collected at 2-h intervals over a 6 -h sampling window at both times and analyzed for adiponectin by Western immunoblotting or by a bovine adiponectin ELISA. The percent reduction in plasma adiponectin between LP and EL is shown. Each bar represents the mean \pm SE of 10 cows. (B) Upon completion of the sampling period on $\mathrm{d}+8$ of EL, dairy cows were randomly assigned to a constant intravenous infusion of saline (saline) or human leptin (hLeptin) for 96 consecutive hours. Plasma samples were collected between 88 and $94 \mathrm{~h}$ of infusion and analyzed for adiponectin concentration with a bovine adiponectin ELISA. Each bar represents the mean $\pm \mathrm{SE}$ of 5 cows per treatment.
Next, we asked whether insulin had an effect on plasma adiponectin in either LP or EL. Dairy cows underwent a hyperinsulinemic-euglycemic clamp for 96 $\mathrm{h}$ in LP and for $48 \mathrm{~h}$ in EL. Plasma insulin increased within $4 \mathrm{~h}$ from 1.8 to $4.0 \mathrm{ng} / \mathrm{mL}$ in $\mathrm{LP}$ and from 0.7 to $2.5 \mathrm{ng} / \mathrm{mL}$ in EL, whereas the plasma glucose concentration remained within $10 \%$ of basal concentration at all times (Leury et al., 2003). Plasma adiponectin fell between LP and EL (Figure 3, stage, $P<0.001$ ) but was unaffected after $48 \mathrm{~h}$ of hyperinsulinemia in either LP or EL. Prolonging the period of hyperinsulinemia to $96 \mathrm{~h}$ during LP was also without effect on plasma adiponectin (basal vs. $96 \mathrm{~h}, 54$ vs. $56 \mathrm{ng} / \mathrm{mL}$ ).

\section{Increasing Plasma GH or Fatty Acids}

Plasma GH and fatty acids increase in periparturient dairy cows (Block et al., 2001; Rhoads et al., 2004). To assess the possible regulatory influence of $\mathrm{GH}$ on plasma adiponectin, LP or EL cows were treated with recombinant bST for 5 consecutive days. Plasma IGF-I was lower in EL than LP cows under basal condition (Figure 4A, stage, $P<0.001$ ). After $5 \mathrm{~d}$ of treatment, plasma IGF-I was increased by GH treatment but to a lesser extent in EL than LP (stage $\times$ GH, $P$ $<0.05$ ). Adipose tissue, on the other hand, remained fully responsive to GH as shown by near identical GHdependent STAT5 phosphorylation across physiological states (Figure 4B). Plasma adiponectin was again reduced in EL relative to LP (Figure 4C, stage, $P<0.05$ ) but was unaffected by GH in either LP or EL.

Finally, the possibility that plasma fatty acids repress plasma adiponectin was evaluated by i.v. infusion of a lipid emulsion in nonpregnant, nonlactating cows in the absence or presence of glucagon for 16 consecutive hours. Intralipid caused a 6 -fold increase in plasma fatty acids within $3 \mathrm{~h}$ of infusion (saline vs. intralipid, 102 vs. $576 \mu M, P<0.001$ ), and this increase persisted for the remainder of the infusion; glucagon had no additional effect on plasma fatty acids (intralipid + glucagon, $613 \mu M$ ). Plasma adiponectin remained unaffected throughout intralipid infusion irrespective of the presence or absence of glucagon (Figure 5).

\section{DISCUSSION}

Insulin resistance is a mechanism used by the modern dairy cow to promote glucose partitioning to the mammary gland at the expense of insulin-sensitive tissues such as skeletal muscle or adipose tissue (Bell and Bauman, 1997; Boisclair et al., 2006). Mechanisms regulating IR during EL in dairy cows are not well understood. In this context, we and others have shown that plasma adiponectin drops in parallel with increased IR in peri- 
parturient dairy cows and that this reduction occurs in the absence of a corresponding change in adiponectin mRNA in adipose tissue (Lemor et al., 2009; Giesy et al., 2012; Mielenz et al., 2013; Singh et al., 2014). Adiponectin is an insulin-sensitizing hormone (Kadowaki et al., 2006; Wang and Scherer, 2016), and therefore, its reduction could contribute to the IR of periparturient dairy cows. Virtually no information is available on mechanisms regulating plasma adiponectin in periparturient dairy cows, prompting us to examine possible regulatory effects of metabolic and hormonal factors changing in a dynamic manner during this period.

The profile of plasma adiponectin in multiparous periparturient dairy cows consists of 2 reciprocal patterns, namely a falling phase over the last 2 to $3 \mathrm{wk}$ of pregnancy followed by a rising phase after parturition (Giesy et al., 2012; Singh et al., 2014). An obvious question is whether the placenta could account for the falling phase through reduced adiponectin production in LP and its expulsion at parturition. More recent studies performed on mid- and late-gestation human placenta, primary human cytotrophoblasts, and placental choriocarcinoma cell lines (Jeg-3, JAR, and BeWo) have ruled out the placenta as a source of adiponectin (Haugen et al., 2006; Pinar et al., 2008; McDonald and Wolfe, 2009). Moreover, adiponectin mRNA abundance was less than $0.5 \%$ of that of maternal adipose tissue at both d 50 and 135 of gestation in the sheep (Y. R. Boisclair, unpublished data). Given the close evolutionary relationship between sheep and cattle, it is unlikely
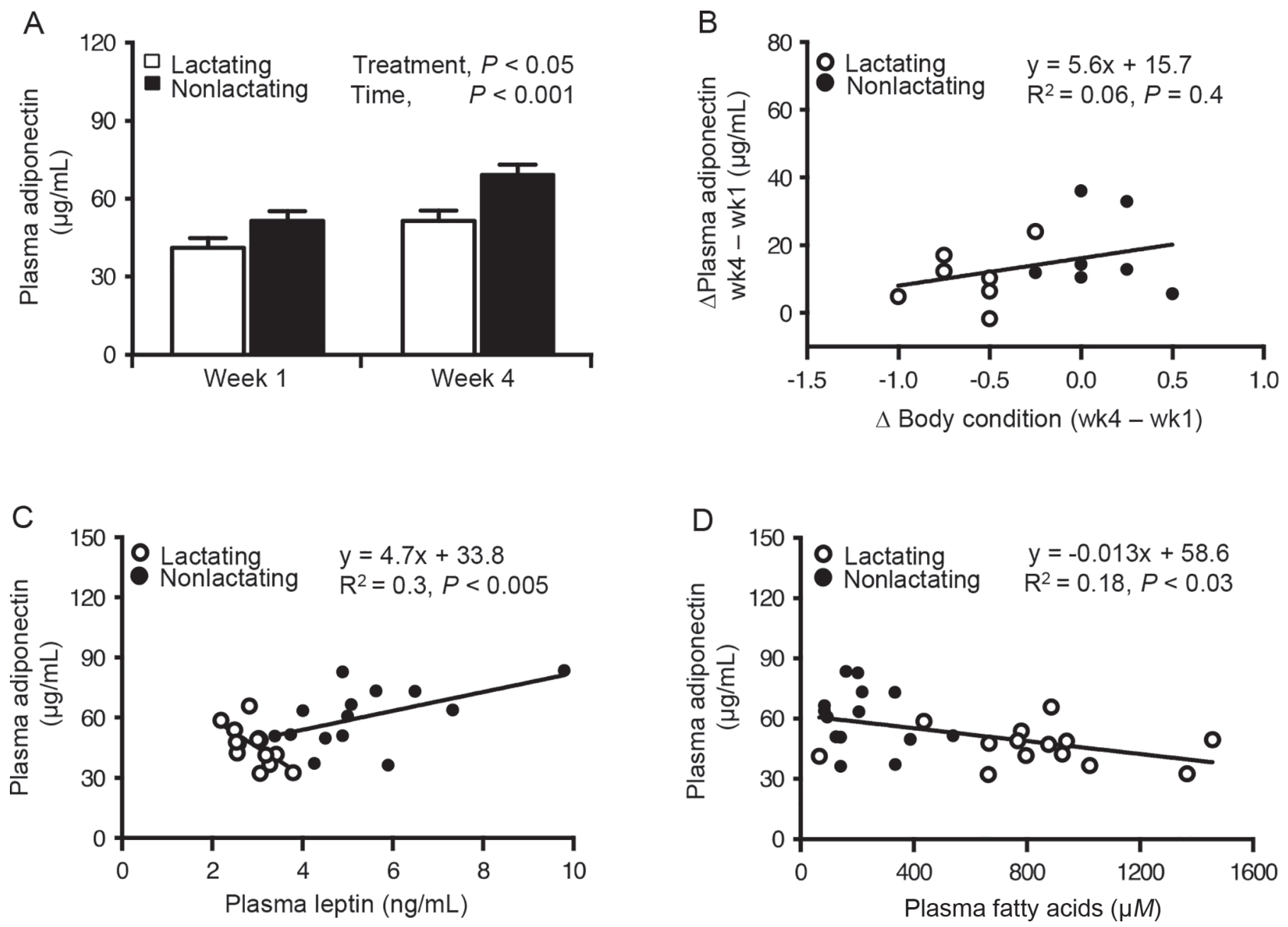

Figure 2. Effect of energy balance after parturition on plasma adiponectin. (A) After parturition, multiparous dairy cows were milked thrice daily (lactating) or never milked (nonlactating). Plasma samples were collected between $\mathrm{d}+5$ and +11 (wk 1 ) and again between $d+26$ and +33 (wk 4) and analyzed for adiponectin concentration with a bovine adiponectin ELISA. Each bar represents the mean \pm SE of 7 cows per treatment. The significant effects of treatment and time are reported. (B) Relationship between the change in plasma adiponectin ( $\Delta$ plasma adiponectin) and the change in body condition ( $\Delta$ body condition) between wk 4 and 1 of the study. (C, D) Relationships between plasma adiponectin and plasma leptin or plasma fatty acids over the first 4 wk following parturition. 
that the bovine placenta is a source of adiponectin and a contributing factor to its falling plasma concentration in late pregnant dairy cows.

In rodents and humans, loss of adiposity as well as NEB are associated with increasing plasma adiponectin (Kadowaki et al., 2006). The relation between energy balance or adiposity and plasma adiponectin has been investigated in nonlactating, nonpregnant dairy cows and in cows from the last month of gestation through the first 12 wk of lactation (Singh et al., 2014; Locher et al., 2015). The contribution of these factors to changes in plasma adiponectin around parturition remains unclear. Accordingly, we used dairy cows dried off immediately after parturition to test the possibility that these factors contribute to the recovery of plasma adiponectin after parturition. In particular, the nonlactating dairy cows completely avoided energy insufficiency after parturition and did not experience a loss of adiposity over the next 4 wk. Against expectations, nonlactating dairy cows not only maintained higher plasma adiponectin than lactating dairy cows but also recovered plasma adiponectin at similar rates as lactating dairy cows even though they failed to lose body condition. Measurable amounts of adiponectin are secreted in milk (Singh et al., 2014), raising the possibility that the higher plasma adiponectin of nonlactating dairy cows relates to absence of adiponectin excretion in milk. However, the fraction of the steady-state plasma adiponectin pool appearing daily in milk is 5\% or less (Singh et al., 2014). Moreover, previous studies in mice and humans suggest a half-life in the 75 to

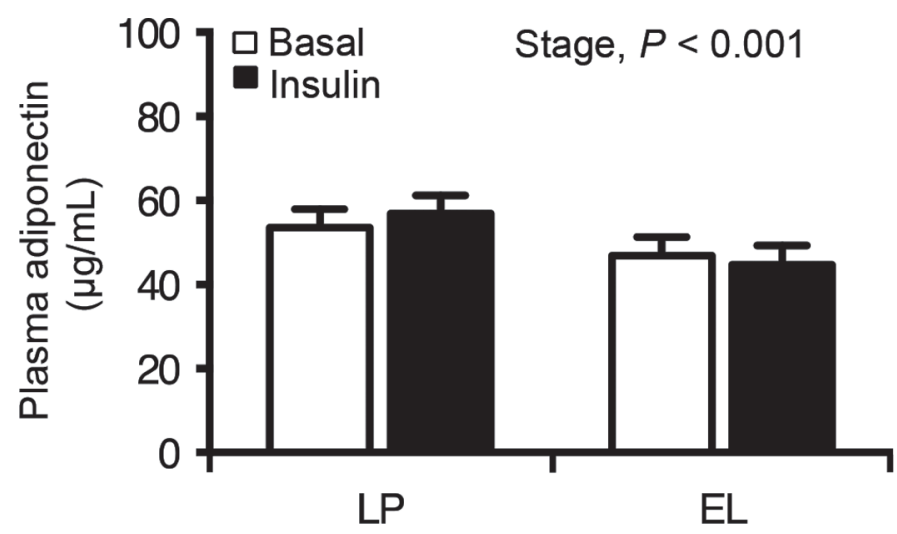

Figure 3. Effect of euglycemic-hyperinsulinemia in late pregnancy and early lactation on plasma adiponectin. Multiparous dairy cows during late pregnancy ( $\mathrm{LP} ; \mathrm{d}-31 \pm 1.5$, relative to parturition on $\mathrm{d}$ $0)$ and early lactation (EL; $+7 \pm 1.6$ ) were studied for $66 \mathrm{~h}$ under basal condition (basal) and for $48 \mathrm{~h}$ during euglycemic-hyperinsulinemia (insulin). Plasma samples collected during the basal period and between 36 and $48 \mathrm{~h}$ of euglycemic-hyperinsulinemia were analyzed for adiponectin concentration with a bovine adiponectin ELISA. Each bar represents the mean $\pm \mathrm{SE}$ of 6 cows. The significant effect of physiological stage (stage) is reported.

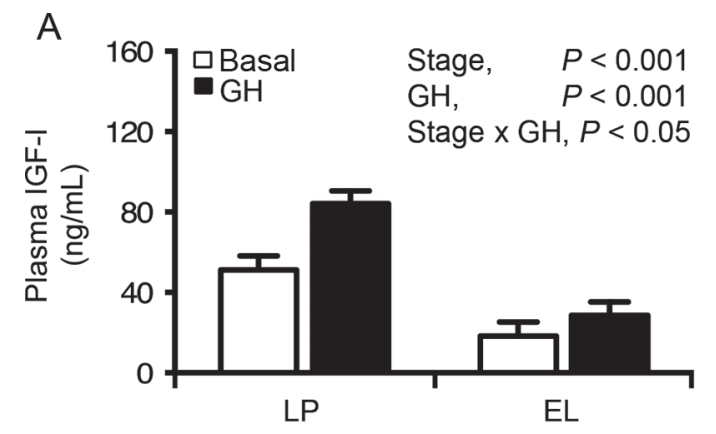

B
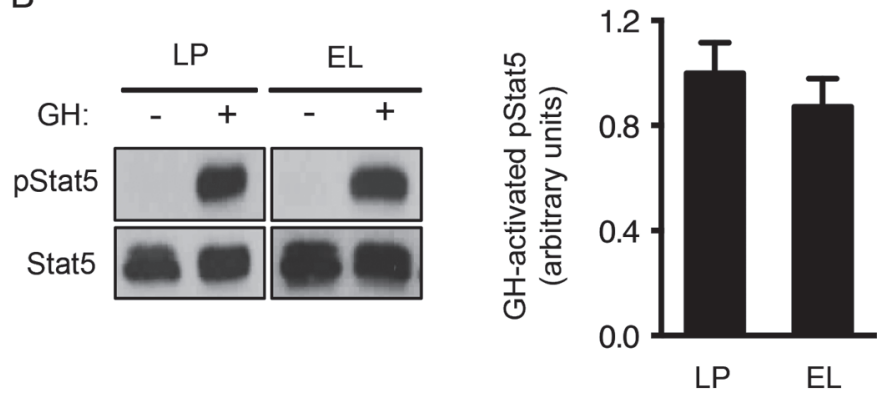

C

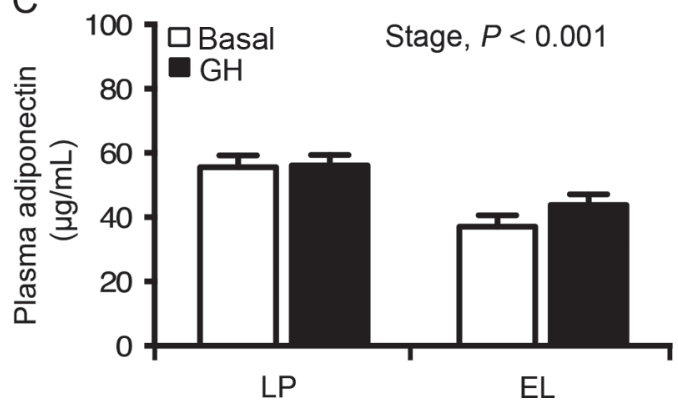

Figure 4. Effect of growth hormone in late pregnancy and early lactation on plasma adiponectin. Multiparous dairy cows were studied in late pregnancy (LP) between $\mathrm{d}-40$ and -36 (relative to parturition on $\mathrm{d} 0$ ) and in early lactation (EL) between $\mathrm{d}+7$ and +11 over a 5 -d period. On the first day of the study period, basal blood samples were collected hourly over a 3 -h period. Adipose tissue was then collected before and 15 min after an intrajugular growth hormone $(\mathrm{GH})$ bolus (20 $\mu \mathrm{g}$ of recombinant $\mathrm{bST} / \mathrm{kg}$ of BW). On d 2 to 5 , cows received daily injections of $\mathrm{GH}$ (40 $\mathrm{mg}$ of recombinant $\mathrm{bST} / \mathrm{d}$ ). (A) Plasma samples collected during the basal period (basal) and on d 5 of GH treatment (GH) were analyzed for plasma IGF-I. Each bar represents the mean \pm SE of 7 cows per treatment and stage. The significant effects of physiological stage (stage), GH treatment, and their interaction are reported. (B) Left: Adipose tissue was obtained on d 1 of the study period immediately before $(-)$ and $15 \mathrm{~min}$ after $(+)$ an intrajugular bolus of recombinant bST $(\mathrm{GH})$. Total cellular extracts were prepared and analyzed for tyrosine phosphorylated Stat5 (pStat5) and total Stat5 (Stat5) by Western immunoblotting. A representative sample is shown for each stage. Right: the GH-dependent pStat5 signal was normalized to total Stat5 signal and expressed relative to LP level with each bar representing the mean $\pm \mathrm{SE}$ of 7 cows. (C) Plasma samples collected during the basal period (basal) and on d 5 of GH treatment $(\mathrm{GH})$ were analyzed for adiponectin concentration with a bovine adiponectin ELISA. Each bar represents the mean \pm SE of 7 cows per stage. The significant effect of physiological stage (stage) is reported. 
150 min range for plasma adiponectin (Hoffstedt et al., 2004; Halberg et al., 2009), implying that this fraction would be even less if calculated on the basis of daily adiponectin production. Therefore, milk adiponectin secretion cannot account for the $21 \%$ difference in plasma adiponectin between lactating and nonlactating dairy cows. Finally, the positive effect of energy balance after parturition on plasma adiponectin is in contrast to the lack of any response when dairy cows experience severe energy insufficiency in mid-lactation (Singh et al., 2014). Overall, our data suggest that the reduction in plasma adiponectin after parturition is driven in part by NEB and that adiponectin recovery after parturition occurs independent of loss of adiposity.

The periparturient period is characterized by rapid reductions in plasma leptin and insulin, raising the possibility that either one or both of these hormones are positive regulators of adiponectin production. In apparent support for this model, plasma adiponectin increases after leptin therapy of leptin-deficient humans and mice (Delporte et al., 2004; Licinio et al., 2004). However, we failed to detect increased plasma adiponectin in EL dairy cows, despite a 3.5-fold increase in plasma leptin. It is also important to mention that the positive effect of leptin therapy seen in leptin-deficient humans and mice is likely a consequence of substantial loss of adiposity rather than a direct leptin effect. In similar fashion to the lack of leptin effects, increasing plasma insulin in either LP or EL was also without any effects on plasma adiponectin. This result is not only

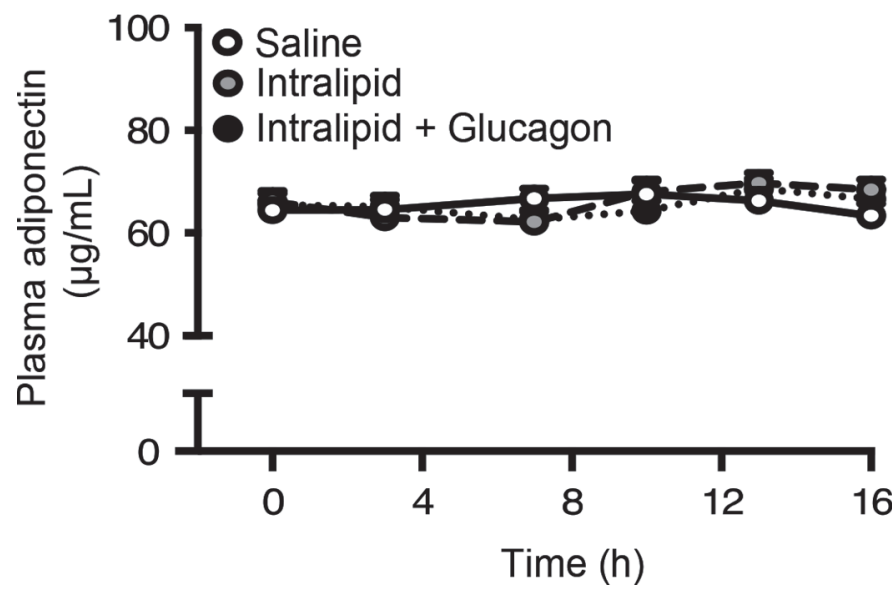

Figure 5. Effect of increased plasma fatty acids on plasma adiponectin. Nonpregnant, nonlactating dairy cows were treated over $16 \mathrm{~h}$ with combinations of i.v. infusion of saline or intralipid $20 \%$ and s.c. injections of saline or glucagon. Treatments were i.v. infusion and s.c. injections of saline (saline), i.v. infusion of intralipid and s.c. injections of saline (intralipid), or i.v. infusion of intralipid and s.c. injection of glucagon (intralipid + glucagon). Plasma samples were collected over the 16-h periods and analyzed for adiponectin concentration with a bovine adiponectin ELISA. Each point represents the mean $\pm \mathrm{SE}$ of 6 cows. inconsistent with a positive role for insulin in the cow but also discordant with results in humans and rodents showing that loss of function mutations of the insulin receptor increase plasma adiponectin, whereas euglycemic-hyperinsulinemia reduces plasma adiponectin (Blüher et al., 2002; Semple et al., 2006; Bobbert et al., 2009). Interestingly, the effects of insulin in humans are not seen on high molecular weight adiponectin (Bobbert et al., 2009). Accordingly, it is possible that the lack of insulin effect in dairy cows relates to circulation of adiponectin predominantly in the high molecular weight form (Giesy et al., 2012).

Interestingly, hypothyroidism in human patients is associated with reduced plasma adiponectin, whereas hyperthyroidism in both humans and rodents has the opposite effect (Yaturu et al., 2004). Periparturient dairy cows are known to experience deficits in the plasma concentration of both thyroid hormones and IGF-I (Reist et al., 2003; Ehrhardt et al., 2016). However, our work shows that plasma adiponectin remained unaffected by correction of the thyroid hormone deficit during the leptin infusion (Ehrhardt et al., 2016) and correction of the IGF-I deficit during the euglycemichyperinsulinemia clamp (Rhoads et al., 2004).

Plasma GH and fatty acids have been implicated as drivers of IR and both are increased in EL dairy cows (Rhoads et al., 2004; Boisclair et al., 2006). In the case of both mice and humans, existing data suggest the possibility that adiponectin mediates the effect of GH on IR. Thus, GH receptor knockout mice have elevated plasma adiponectin and insulin sensitivity despite increased fatness (Lubbers et al., 2013). Similarly, increased insulin sensitivity and plasma adiponectin coexist in patients lacking a functional $\mathrm{GH}$ receptor (Laron dwarf) and both are reduced in patients with excessive GH secretion (Lam et al., 2004; Kanety et al., 2009). Therefore, we tested the possibility that GH inhibits adiponectin production by treating LP and EL dairy cows with exogenous GH. As previously shown, plasma IGF-I was lower in EL than LP, and GH increased plasma IGF-I to a larger extent in LP than EL (Block et al., 2001; Rhoads et al., 2004). The attenuated increase in plasma IGF-I reflects reduced hepatic $\mathrm{GH}$ responsiveness as a result of loss of $\mathrm{GH}$ receptor expression in EL (Wook Kim et al., 2004). On the other hand, our data show that adipose tissue remains GH-responsive in both LP and EL as demonstrated by equally robust GH-dependent STAT5 activation across physiological states. Despite this, GH treatment for 5 consecutive days had no effect on plasma adiponectin irrespective of physiological state.

Plasma fatty acids also contribute to IR (Pires et al., 2007) particularly when their levels are excessively elevated in EL as a consequence of overnutrition, obe- 
sity, or both in LP (Holtenius et al., 2003; Janovick et al., 2011). Plasma fatty acids promote IR by promoting synthesis of lipid intermediates such as ceramide species and diacylglycerol and by activating the production of pro-inflammatory cytokines such as tumor necrosis factor a (Shi et al., 2006; Sadri et al., 2010; Rico et al., 2015). Interestingly, intralipid, ceramide, and tumor necrosis factor $\alpha$ have been shown to repress adiponectin production in vivo and in vitro (Lim et al., 2008; Bobbert et al., 2009; Correnti et al., 2014). Despite these data implicating plasma fatty acids as a repressor of adiponectin production, our data show that a 6 -fold increase in plasma fatty acids during intralipid infusion had no effect on plasma adiponectin. It remains possible that the 13-h period of exposure to elevated plasma fatty acids was too short to elicit a reduction in plasma adiponectin.

In summary, plasma adiponectin in transition dairy cows is remarkably unresponsive to metabolic and hormonal factors changing in a dynamic manner around parturition period and shown to regulate circulating levels in other species and contexts. Future efforts should focus on the role of other important hormones (i.e., FGF21, resistin, etc.) as well as on depot-specific factors (subcutaneous vs. visceral or bone marrow adipocytes).

\section{ACKNOWLEDGMENTS}

This material is based on work supported by the National Institute of Food and Agriculture, USDA (Washington, DC), under award number 2014-67015-21592 and Hatch/Multistate project under 1000962.

\section{REFERENCES}

Bell, A. W., and D. E. Bauman. 1997. Adaptations of glucose metabolism during pregnancy and lactation. J. Mammary Gland Biol. Neoplasia 2:265-278.

Block, S. S., W. R. Butler, R. A. Ehrhardt, A. W. Bell, M. E. Van Amburgh, and Y. R. Boisclair. 2001. Decreased concentration of plasma leptin in periparturient dairy cows is caused by negative energy balance. J. Endocrinol. 171:339-348.

Blüher, M., M. D. Michael, O. D. Peroni, K. Ueki, N. Carter, B. B. Kahn, and C. R. Kahn. 2002. Adipose tissue selective insulin receptor knockout protects against obesity and obesity-related glucose intolerance. Dev. Cell 3:25-38.

Bobbert, T., J. Weicht, K. Mai, M. Möhlig, A. F. H. Pfeiffer, and J. Spranger. 2009. Acute hyperinsulinaemia and hyperlipidaemia modify circulating adiponectin and its oligomers. Clin. Endocrinol. (Oxf.) 71:507-511. https://doi.org/10.1111/j.1365-2265.2008 .03519.x.

Boisclair, Y. R., S. R. Wesolowski, J. W. Kim, and R. A. Ehrhardt. 2006. Role of growth hormone and leptin in the periparturient dairy cow. K. Sejrsen, T. Hveplund, and M. O. Nielsen, ed. Wageningen Academic Publishers, Wageningen, the Netherlands.

Caixeta, L. S., S. L. Giesy, C. S. Krumm, J. W. Perfield 2nd, A. Butterfield, K. M. Schoenberg, D. C. Beitz, and Y. R. Boisclair. 2017. Effect of circulating glucagon and free fatty acids on hepatic
FGF21 production in dairy cows. Am. J. Physiol. Regul. Integr. Comp. Physiol. In press.

Correnti, J. M., E. Juskeviciute, A. Swarup, and J. B. Hoek. 2014. Pharmacological ceramide reduction alleviates alcohol-induced steatosis and hepatomegaly in adiponectin knockout mice. Am. J. Physiol. Gastrointest. Liver Physiol. 306:G959-G973. https://doi .org/10.1152/ajpgi.00395.2013.

Delporte, M.-L., S. A. El Mkadem, M. Quisquater, and S. M. Brichard. 2004. Leptin treatment markedly increased plasma adiponectin but barely decreased plasma resistin of ob/ob mice. Am. J. Physiol. Endocrinol. Metab. 287:E446-E453. https://doi.org/10 .1152/ajpendo.00488.2003.

Ehrhardt, R. A., A. Foskolos, S. L. Giesy, S. R. Wesolowski, C. S. Krumm, W. Butler, S. Quirk, M. R. Waldron, and Y. R. Boisclair. 2016. Increased plasma leptin attenuates adaptive metabolism in early lactating dairy cows. J. Endocrinol. https://doi.org/10.1530/ JOE-16-0031.

Giesy, S. L., B. Yoon, W. B. Currie, J. W. Kim, and Y. R. Boisclair 2012. Adiponectin deficit during the precarious glucose economy of early lactation in dairy cows. Endocrinology 153:5834-5844. https://doi.org/10.1210/en.2012-1765.

Halberg, N., T. D. Schraw, Z. V. Wang, J.-Y. Kim, J. Yi, M. P. Hamilton, K. Luby-Phelps, and P. E. Scherer. 2009. Systemic fate of the adipocyte-derived factor adiponectin. Diabetes 58:1961-1970. https://doi.org/10.2337/db08-1750.

Haugen, F., T. Ranheim, N. K. Harsem, E. Lips, A. C. Staff, and C. A. Drevon. 2006. Increased plasma levels of adipokines in preeclampsia: relationship to placenta and adipose tissue gene expression. Am. J. Physiol. Endocrinol. Metab. 290:E326-E333. https://doi .org/10.1152/ajpendo.00020.2005.

Hoffstedt, J., E. Arvidsson, E. Sjölin, K. Wåhlén, and P. Arner. 2004 Adipose tissue adiponectin production and adiponectin serum concentration in human obesity and insulin resistance. J. Clin. Endocrinol. Metab. 89:1391-1396. https://doi.org/10.1210/jc.2003 $-031458$.

Holtenius, K., S. Agenäs, C. Delavaud, and Y. Chilliard. 2003. Effects of feeding intensity during the dry period. 2. metabolic and hormonal responses. J. Dairy Sci. 86:883-891. https://doi.org/10 .3168/jds.S0022-0302(03)73671-6.

Hotta, K., T. Funahashi, N. L. Bodkin, H. K. Ortmeyer, Y. Arita, B. C. Hansen, and Y. Matsuzawa. 2001. Circulating concentrations of the adipocyte protein adiponectin are decreased in parallel with reduced insulin sensitivity during the progression to type 2 diabetes in rhesus monkeys. Diabetes 50:1126-1133.

Janovick, N. A., Y. R. Boisclair, and J. K. Drackley. 2011. Prepartum dietary energy intake affects metabolism and health during the periparturient period in primiparous and multiparous Holstein cows. J. Dairy Sci. 94:1385-1400. https://doi.org/10.3168/jds.2010 $-3303$.

Kadowaki, T., T. Yamauchi, N. Kubota, K. Hara, K. Ueki, and K. Tobe. 2006. Adiponectin and adiponectin receptors in insulin resistance, diabetes, and the metabolic syndrome. J. Clin. Invest. 116:1784-1792. https://doi.org/10.1172/JCI29126.

Kanety, H., R. Hemi, S. Ginsberg, C. Pariente, E. Yissachar, E. Barhod, T. Funahashi, and Z. Laron. 2009. Total and high molecular weight adiponectin are elevated in patients with Laron syndrome despite marked obesity. Eur. J. Endocrinol. 161:837-844. https:// doi.org/10.1530/EJE-09-0419.

Kim, J.-Y., E. van de Wall, M. Laplante, A. Azzara, M. E. Trujillo, S. M. Hofmann, T. Schraw, J. L. Durand, H. Li, G. Li, L. A Jelicks, M. F. Mehler, D. Y. Hui, Y. Deshaies, G. I. Shulman, G. J. Schwartz, and P. E. Scherer. 2007. Obesity-associated improvements in metabolic profile through expansion of adipose tissue. J. Clin. Invest. 117:2621-2637. https://doi.org/10.1172/JCI31021.

Lam, K. S.-L., A. Xu, K. C.-B. Tan, L.-C. Wong, S.-C. Tiu, and S. Tam. 2004. Serum adiponectin is reduced in acromegaly and normalized after correction of growth hormone excess. J. Clin. Endocrinol. Metab. 89:5448-5453. https://doi.org/10.1210/jc.2003 $-032023$.

Lemor, A., A. Hosseini, H. Sauerwein, and M. Mielenz. 2009. Transition period-related changes in the abundance of the mRNAs of 
adiponectin and its receptors, of visfatin, and of fatty acid binding receptors in adipose tissue of high-yielding dairy cows. Domest. Anim. Endocrinol. 37:37-44. https://doi.org/10.1016/j.domaniend 2009.01.004.

Leury, B. J., L. H. Baumgard, S. S. Block, N. Segoale, R. A. Ehrhardt, R. P. Rhoads, D. E. Bauman, A. W. Bell, and Y. R. Boisclair. 2003. Effect of insulin and growth hormone on plasma leptin in periparturient dairy cows. Am. J. Physiol. Regul. Integr. Comp. Physiol. 285:R1107-R1115. https://doi.org/10.1152/ajpregu .00320 .2003 .

Licinio, J., S. Caglayan, M. Ozata, B. O. Yildiz, P. B. de Miranda, F. O'Kirwan, R. Whitby, L. Liang, P. Cohen, S. Bhasin, R. M. Krauss, J. D. Veldhuis, A. J. Wagner, A. M. DePaoli, S. M. McCann, and M.-L. Wong. 2004. Phenotypic effects of leptin replacement on morbid obesity, diabetes mellitus, hypogonadism, and behavior in leptin-deficient adults. Proc. Natl. Acad. Sci. USA 101:4531-4536. https://doi.org/10.1073/pnas.0308767101.

Lim, J.-Y., W. H. Kim, and S. I. Park. 2008. GO6976 prevents TNFalpha-induced suppression of adiponectin expression in 3T3-L1 adipocytes: Putative involvement of protein kinase C. FEBS Lett. 582:3473-3478. https://doi.org/10.1016/j.febslet.2008.09.012.

Locher, L., S. Häussler, L. Laubenthal, S. P. Singh, J. Winkler, A. Kinoshita, Á. Kenéz, J. Rehage, K. Huber, H. Sauerwein, and S. Dänicke. 2015. Effect of increasing body condition on key regulators of fat metabolism in subcutaneous adipose tissue depot and circulation of nonlactating dairy cows. J. Dairy Sci. 98:1057-1068. https://doi.org/10.3168/jds.2014-8710.

Lubbers, E. R., E. O. List, A. Jara, L. Sackman-Sala, J. CordobaChacon, M. D. Gahete, R. D. Kineman, R. Boparai, A. Bartke, J. J. Kopchick, and D. E. Berryman. 2013. Adiponectin in mice with altered GH action: links to insulin sensitivity and longevity? J. Endocrinol. 216:363-374. https://doi.org/10.1530/JOE-12-0505.

McDonald, E. A., and M. W. Wolfe. 2009. Adiponectin attenuation of endocrine function within human term trophoblast cells. Endocrinology 150:4358-4365. https://doi.org/10.1210/en.2009-0058.

Mielenz, M., B. Mielenz, S. P. Singh, C. Kopp, J. Heinz, S. Häussler, and H. Sauerwein. 2013. Development, validation, and pilot application of a semiquantitative Western blot analysis and an ELISA for bovine adiponectin. Domest. Anim. Endocrinol. 44:121-130. https://doi.org/10.1016/j.domaniend.2012.10.004.

NRC. 2001. Nutrient Requirements of Dairy Cattle: 7th rev. ed. Natl. Acad. Press, Washington, DC.

Pinar, H., S. Basu, K. Hotmire, L. Laffineuse, L. Presley, M. Carpenter, P. M. Catalano, and S. Hauguel-de Mouzon. 2008. High molecular mass multimer complexes and vascular expression contribute to high adiponectin in the fetus. J. Clin. Endocrinol. Metab. 93:2885-2890. https://doi.org/10.1210/jc.2008-0009.

Pires, J. A. A., A. H. Souza, and R. R. Grummer. 2007. Induction of hyperlipidemia by intravenous infusion of tallow emulsion causes insulin resistance in Holstein cows. J. Dairy Sci. 90:2735-2744. https://doi.org/10.3168/jds.2006-759.

Reist, M., D. Erdin, D. von Euw, K. Tschuemperlin, H. Leuenberger, C. Delavaud, Y. Chilliard, H. M. Hammon, N. Kuenzi, and J. W. Blum. 2003. Concentrate feeding strategy in lactating dairy cows: metabolic and endocrine changes with emphasis on leptin. J. Dairy Sci. 86:1690-1706. https://doi.org/10.3168/jds.S0022 $-0302(03) 73755-2$
Rhoads, R. P., J. W. Kim, B. J. Leury, L. H. Baumgard, N. Segoale, S. J. Frank, D. E. Bauman, and Y. R. Boisclair. 2004. Insulin increases the abundance of the growth hormone receptor in liver and adipose tissue of periparturient dairy cows. J. Nutr. 134:1020-1027.

Rico, J. E., V. V. R. Bandaru, J. M. Dorskind, N. J. Haughey, and J. W. McFadden. 2015. Plasma ceramides are elevated in overweight Holstein dairy cows experiencing greater lipolysis and insulin resistance during the transition from late pregnancy to early lactation. J. Dairy Sci. 98:7757-7770. https://doi.org/10.3168/jds.2015 -9519 .

Sadri, H., R. M. Bruckmaier, H. R. Rahmani, G. R. Ghorbani, I. Morel, and H. A. van Dorland. 2010. Gene expression of tumour necrosis factor and insulin signalling-related factors in subcutaneous adipose tissue during the dry period and in early lactation in dairy cows. J. Anim. Physiol. Anim. Nutr. (Berl.) 94:e194-e202. https://doi.org/10.1111/j.1439-0396.2010.01005.x.

Schoenberg, K. M., S. L. Giesy, K. J. Harvatine, M. R. Waldron, C. Cheng, A. Kharitonenkov, and Y. R. Boisclair. 2011. Plasma FGF21 is elevated by the intense lipid mobilization of lactation. Endocrinology 152:4652-4661. https://doi.org/10.1210/en.2011 -1425 .

Semple, R. K., M. A. Soos, J. Luan, C. S. Mitchell, J. C. Wilson, M. Gurnell, E. K. Cochran, P. Gorden, V. K. K. Chatterjee, N. J. Wareham, and S. O'Rahilly. 2006. Elevated plasma adiponectin in humans with genetically defective insulin receptors. J. Clin. Endocrinol. Metab. 91:3219-3223. https://doi.org/10.1210/jc.2006 -0166 .

Shi, H., M. V. Kokoeva, K. Inouye, I. Tzameli, H. Yin, and J. S. Flier. 2006. TLR4 links innate immunity and fatty acid-induced insulin resistance. J. Clin. Invest. 116:3015-3025. https://doi.org/ 10.1172/JCI28898.

Singh, S. P., S. Häussler, J. J. Gross, F. J. Schwarz, R. M. Bruckmaier, and H. Sauerwein. 2014. Short communication: circulating and milk adiponectin change differently during energy deficiency at different stages of lactation in dairy cows. J. Dairy Sci. 97:15351542. https://doi.org/10.3168/jds.2013-7598.

Venn-Watson, S., C. R. Smith, S. Stevenson, C. Parry, R. Daniels, E. Jensen, V. Cendejas, B. Balmer, M. Janech, B. A. Neely, and R. Wells. 2013. Blood-based indicators of insulin resistance and metabolic syndrome in bottlenose dolphins (Tursiops truncatus). Front. Endocrinol. (Lausanne) 4:136. https://doi.org/10.3389/fendo.2013 .00136 .

Wang, Y., K. S. L. Lam, M. Yau, and A. Xu. 2008. Post-translational modifications of adiponectin: mechanisms and functional implications. Biochem. J. 409:623-633. https://doi.org/10.1042/ BJ20071492

Wang, Z. V., and P. E. Scherer. 2016. Adiponectin, the past two decades. J. Mol. Cell Biol. 8:93-100. https://doi.org/10.1093/jmcb/ mjw011.

Wook Kim, J., R. P. Rhoads, S. S. Block, T. R. Overton, S. J. Frank, and Y. R. Boisclair. 2004. Dairy cows experience selective reduction of the hepatic growth hormone receptor during the periparturient period. J. Endocrinol. 181:281-290.

Yaturu, S., S. Prado, and S. R. Grimes. 2004. Changes in adipocyte hormones leptin, resistin, and adiponectin in thyroid dysfunction. J. Cell. Biochem. 93:491-496. https://doi.org/10.1002/jcb.20188. 